\title{
Small mammals (Rodentia) present in Tyto furcata (Temminck, 1827) (Strigiformes, Tytonidae) pellets from the Reserva Natural da Guaricica, Antonina, coastal Paraná, Brazil
}

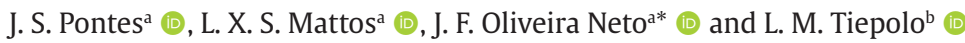 \\ aUniversidade Estadual do Paraná - UNESPAR, Campus de Paranaguá, Laboratório Multidisciplinar de Estudos Animais, Paranaguá, PR, Brasil \\ bUniversidade Federal do Paraná - UFPR, Campus de Matinhos, Laboratório de Biodiversidade e Conservação, Matinhos, PR, Brasil
}

One method to determine the presence of non-flying small mammals is the use of owl pellets or regurgitates. Tyto furcata is an owl species found in many types of environment, varying from untouchable forests to urban areas. The species has typical nocturnal habits and a varied diet of mammals (including rodents, marsupials, bats), amphibians, reptiles, and even other birds (Machado, 2011) and has been shown to move on average $1 \mathrm{~km}$ (rarely $2 \mathrm{~km}$ ) from the nesting site to foraging areas (Taylor, 1994).

Inspired by the exemple of successful inventories (Stutz et al., 2020; Cherem et al., 2018; Lemos et al., 2015), which used bones and teeth present in pellets of owls in South America to access the diversity of small mammals, this research aimed to assess the rodent diversity in Reserva Natural da Guaricica (RNG). It has 8,600.32 ha entirely located within the municipality of Antonina, on the coastal plain, eastern Paraná State, Brazil $\left(25^{\circ} 24^{\prime}-25^{\circ} 41^{\prime} \mathrm{S}\right.$, $\left.48^{\circ} 64^{\prime}-48^{\circ} 74^{\prime} \mathrm{W}\right)$. It is in one of the largest continuous remnants of the Atlantic Forest in Brazil, preserving natural vegetation formations of the Dense Ombrophilous Forest. However, 1,500 ha are of degraded areas in recovery process. The climate of the region is classified as Cfa, subtropical humid mesothermic, according to the Köppen system.

Sampling of $T$. furcata pellets began in July 2015 and was performed every two weeks for twelve months. The pellets were found in the Centro de Educação Ambiental (CEA), which is a building used as a perch and main nest. Each collected pellet was packed in a plastic bag, numbered and labelled with date and location. For the preparation of the pellets, they were immersed in $70 \%$ alcohol for two hours, followed by separation of the osteological remains from hairs. Specimens were identified based on cranial structures and teeth (incisors and molars) observed under a microscope and compared with the reference collection of Biodiversity Conservation Laboratory from Universidade Federal do Paraná (UFPR).

A total of 2,900 pellets were collected, as most pellets didn't contain enough cranial structures for identification, we recovered 133 individual rodents representing seven taxa: Oligoryzomys sp., Nectomys squamipes (Brants, 1827), Akodon sp., Holochilus brasiliensis (Desmarest, 1819),
Brucepattersonius sp., Oxymycterus sp. and Euryoryzomys russatus (Wagner, 1848) (Figure 1). Quadros and Tiepolo (2003), and Silveira (2012), employed conventional trapping methods in RNG, and registered altogether 11 species in Rodentia. Four of the genus present in our samples, Nectomys, Brucepattersonius, Holochilus and Oxymycterus, were not present in those samples. The orders Didelphimorphia and Chiroptera, one bird and one Anura were also present in the owl pellet samples, but exceedingly rare and difficult to identify.

Quadros and Tiepolo (2003) and Silveira (2012) were more successful in sampling and identifying not only Rodentia (11 species), but also Didelphimorpha (6 species) using conventional traps. Eight genus of Rodentia were absent from our samples, in some cases, because they are too large or more diurnal species to be prey by $T$. furcate: Sciurus aestuans (Linnaeus, 1766), Hydrochaeris hydrochaeris [Linnaeus, 1766], Cavia aperea Erxleben, 1777, Dasyprocta azarae Lichtenstein, 1823, Agouti paca (Linnaeus, 1769). In three cases, the absent species were a potential prey of T. furcate: Delomys dorsalis (Hensel, 1872), Sooretamys angouya (Fischer, 1814), and Oryzomys sp.. Only three taxa were shared between all searches in reserve (0. nigripes, Akodon sp. and E. russatus). Absence of invasive species, as Mus musculus (Linnaeus, 1758) and Rattus rattus (Linnaeus, 1758) suggests that, despite more generalist species are present, area is characterized by low degree of disturbance.

The species Oligoryzomys sp. (83 individuals, 62\%) and Akodon sp. (13 individuals, 10\%) are frequent in areas that have suffered some type of perturbation (Pardini and Umetsu, 2006; Quintela et al., 2012). It makes sense, because 1,500 ha are of degraded areas in recovery process. N. squamipes (Brants, 1827) was the second most frequent taxon with seventeen individuals present in the pellets (13\%). According to Oliveira and Bonvicino (2006), this rodent lives close to water courses. The present study recorded the occurrence of $H$. brasiliensis, (six individuals, $4 \%$ ) which represents the first documented occurrence of this species along the north coast of the state of Paraná. The species of the genus Holochilus also inhabit humid areas close to water courses such as rivers, lakes and

*e-mail: oliveira.neto.bio@gmail.com

Received: December 28, 2020 - Accepted: April 6, 2021

This is an Open Access article distributed under the terms of the Creative Commons Attribution License, which permits unrestricted use, distribution, and reproduction in any medium, provided the original work is properly cited. 


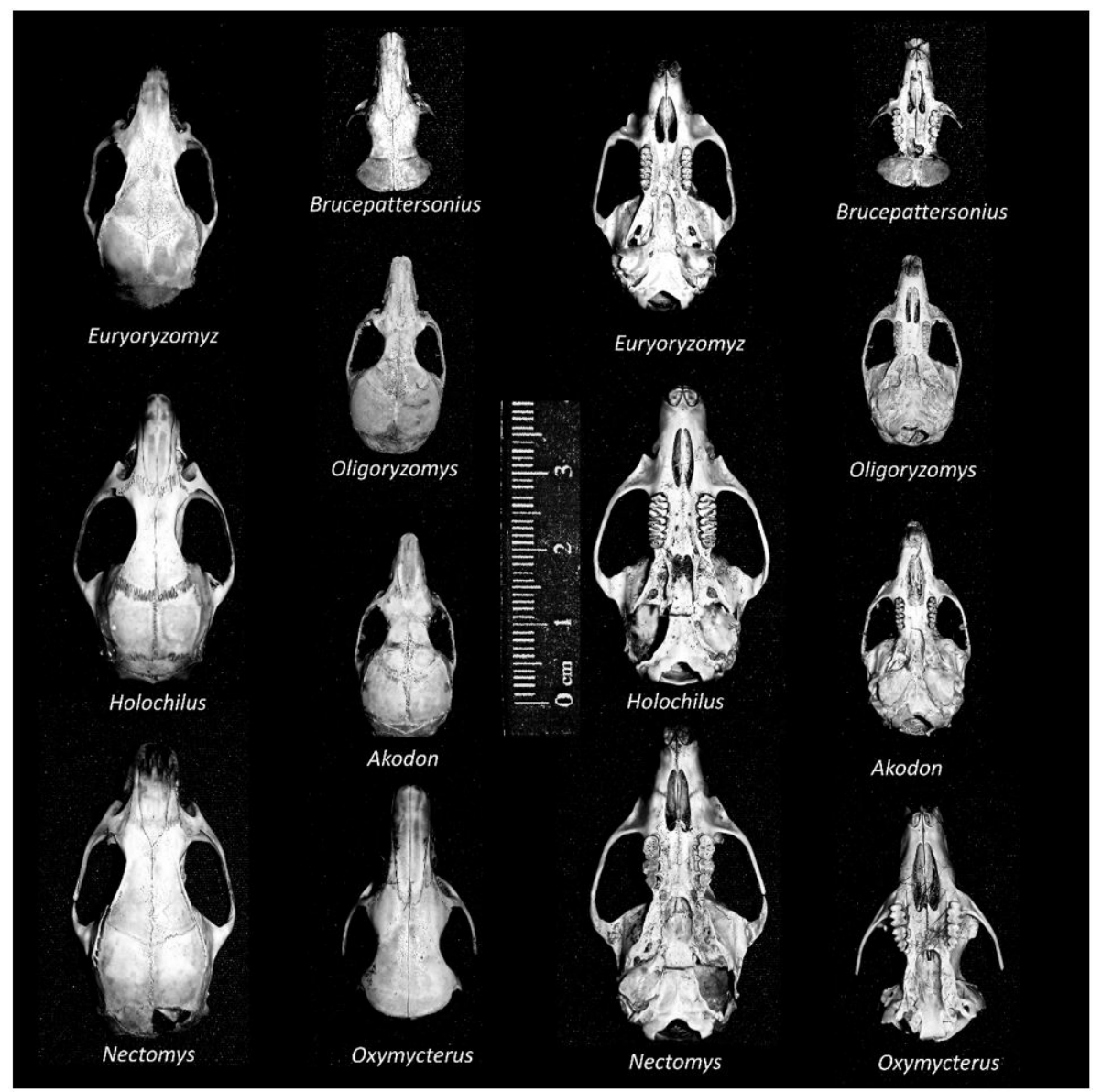

Figure 1. Skulls found in Tyto furcata pellets from the Reserva Natural da Guaricica, identified by genus. Left to the rule, skulls are shown in dorsal view. Right to the rule, skulls are shown in ventral view.

streams, and are typical of open areas in South America (Hershkovitz, 1955). The increase in areas irrigated by artificial channels and the abundance of tributaries of the Cachoeira river basin in the region favor the presence of N. squamipes and H. brasiliensis.

The genus Brucepattersonius (eight individuals, $6 \%$ ) can be found in undisturbed and non-fragmented Ombrophilous Forest and Seasonal Deciduous Forest (Pardini et al., 2005). The species Euryoryzomys russatus (Three individuals, 2\%) can serve as a habitat quality bioindicator, since it is strongly affected by the loss and fragmentation of forest (Pardini et al., 2005; Umetsu et al., 2008). This is one of the most common species in forests with excellent state of preservation in littoral of Paraná (Mochi-Junior, 2014; Gatto-Almeida et al., 2016). There were also three Oxymycterus (2\%).

The current study area is during an ecological succession transition, since it was old cattle pasture, and its reforestation is recent. It is possible that the quality of its surroundings has enabled the occupation of sensitive species. This record shows the importance of using owl pellets for small mammal survey since the region has been intensively sampled over the past few decades without capturing this species by traditional methods. New information obtained here for the study area shows how important this method can be as alternative to traditional trapping inventories.

\section{References}

CHEREM, J.J., HADLER, P., STUTZ, N.S. and PARDIÑAS, U.F.J., 2018. Pequenos mamíferos (Didelphimorphia, Chiroptera e Rodentia) em egagropilos de Tyto furcata (coruja-das-igrejas) (Aves, Tytonidae) do sul do Brasil. Biotemas, vol. 31, no. 3, pp. 43-58. http://dx.doi.org/10.5007/2175-7925.2018v31n3p43.

GATTO-ALMEIDA, F., PONTES, J.S., SBALQUEIRO, I.J., HASS, I., TIEPOLO, L.M. and QUADROS, J., 2016. Diversidade, biogeografia, caracterização cariotípica e tricológica dos pequenos mamíferos não voadores do Parque Estadual Rio da Onça, Litoral Sul do Paraná. Papéis Avulsos de Zoologia, vol. 56, pp. 2-28.

HERSHKOVITZ, P., 1955. South American marsh rats, genus Holochilus, with a summary of sigmodont rodents. Fieldiana. Zoology, vol. 37, no. 1, pp. 639-673.

LEMOS, H.M.L., SILVA, C.A.O., PATIU, F.M. and GONÇALVES, P.L., 2015. Barn Owl pellets (Aves: Tyto furcata) reveal a higher mammalian richness in the Restinga de Jurubatiba National Park, Southeastern Brazil. Biota Neotropica, vol. 15, no. 2, e20140121. http://dx.doi.org/10.1590/1676-06032015012114. 
MACHADO, F.S.C.A., 2011. Efeito das alterações agrícolas na coruja dastorres (Tyto alba): variação na abundância e no uso do espaço. Lisboa: Universidade de Lisboa. Dissertação de Mestrado em Ecologia.

MOCHI-JUNIOR, C.M., 2014. Composição taxonômica e avaliação da diversidade da fauna de pequenos mamíferos não-voadores na formação submontana do Parque Nacional Saint-Hilaire/Lange, Mata Atlântica costeira do Paraná. Curitiba: Universidade Federal do Paraná. Dissertação de Mestrado em Zoologia..

OLIVEIRA, J.A. and BONVICINO, C.R., 2006. Ordem Rodentia. In: N.R. REIS, A.L. PERACCHI, W. A. PEDRO and I.P. LIMA, eds. Mamíferos do Brasil. 1. ed. Londrina: Nélio R. dos Reis, pp. 347-406.

PARDINI, R. and UMETSU, F., 2006. Pequenos mamíferos nãovoadores da Reserva Florestal do Morro Grande - Distribuição das espécies e da diversidade em uma área de Mata Atlântica. Biota Neotropica, vol. 6, no. 2, pp.1-22. http://dx.doi.org/10.1590/ S1676-06032006000200007.

PARDINI, R., SOUZA, S.M., BRAGA-NETO, R. and METZER, J.P., 2005. The role of forest structure, fragment size and corridors in maintaining small mammal abundance and diversity in an Atlantic forest landscape. Biological Conservation, vol. 124, no. 2, pp. 253-266. http://dx.doi.org/10.1016/j.biocon.2005.01.033.

QUADROS, J. and TIEPOLO, L.M., 2003. Mamíferos. In: SOCIEDADE DE PESQUISA EM VIDA SELVAGEM E EDUCAÇÃO AMBIENTAL -
SPVS, ed. Diagnóstico da fauna: Reserva Natural Rio Cachoeira, Antonina, Paraná. Curitiba. Curitiba. Relatório técnico interno.

QUINTELA, F.M., SANTOS, M.B., CHRISTOFF, A.U. and GAVA, A., 2012. Non-volant small mammals (Didelphimorphia, Rodentia) in two forest fragments in Rio Grande, Rio Grande do Sul Coastal Plain, Brazil. Biota Neotropica, vol. 12, no. 1, pp. 261-266. http:// dx.doi.org/10.1590/S1676-06032012000100021.

SILVEIRA, F., 2012. Estrutura populacional de pequenos mamíferos na reserva da Cachoeira, APA de Guaraqueçaba, Paraná. Curitiba: Universidade Federal do Paraná. Dissertação de Mestrado em Zoologia.

STUTZ, N.S., HADLER, P., CHEREM, J.J. and PARDIÑAS, U.F.J., 2020. Small mammal diversity in Semi-deciduous Seasonal Forest of the southernmost Brazilian Pampa: the importance of owl pellets for rapid inventories in human-changing ecosystems. Papéis Avulsos de Zoologia, vol. 60, e20206025.

TAYLOR, I., 1994. Barn owls: predator-prey relationships and conservation. 2nd ed. Cambridge: Cambridge University Press, 304 p.

UMETSU, F., METZGER, J.P. and PARDINI, R., 2008. Importance of estimating matrix quality for modeling species distribution in complex tropical landscapes: a test with Atlantic forest small mammals. Ecography, vol. 31, no. 3, pp. 359-370. http://dx.doi. org/10.1111/j.0906-7590.2008.05302.x. 